\title{
FACTORS CONTRIBUTING TO THE DECREASE OF PRICES FOR PORK AND THE DECLINE OF PIG PRODUCTION PROFITABILITY
}

\author{
N.Karlova
}

The lowering of import duties on pork from August 2012 following Russia's accession to the WTO resulted in the decrease of prices for this product and the decline of profitability of domestic pig production. Combined with a whole set of other factors this dragged the problems of the sector forth into 2013.

A short rise of prices for pork in summer 2012 (due to the seasonal growth of demand and the imposition of embargo on the import of commercial livestock from the EU in order to prevent the spread of "Schmallenberg" virus) was superseded by their sharp drop from the end of August 2012 (Fig. 1). In 2013 the decrease of prices continued. As a result, from September 2012 to March 2013 prices received by domestic producers for pork (slaughter weight, VAT included) fell by an average 30\%: from $\mathrm{Rb} 136$ to $\mathrm{Rb} 97$ per $\mathrm{kg}$ in Belgorod oblast, from $\mathrm{Rb} 127$ to $89 \mathrm{Rb}$ per kg in Krasnodar Krai and from Rb 129 to Rb 91 in Moscow oblast. Beginning from April 2013 prices for pork started to grow but so far have failed to reach the respective 2012 level. The drop of prices conditioned the decline of pig production profitability.

The increase of pork imports due to lower rates of import duties (that came into effect following Russia's accession to the WTO in August 2012) was not the only reason of negative price dynamics in the sector. Other factors contributed to the situation as well:

- a remarkable increase of domestic pork production in corporate farms at the end of 2012;

- the drought and higher prices for feeds in the past year:

- low competitiveness of the sector;

- annual seasonal reduction of demand for meat in March-April 2013.

After joining the WTO Russia lowered the duty on import of pork within the quota from 15\% (but not less than 0.25 euro per $\mathrm{kg}$ ) down to $0 \%$, on import of pork out of the quota - from $75 \%$ (but not less than 1.5 euro per $\mathrm{kg}$ ) to $65 \%$, on import of live pigs - from $40 \%$ (but not less than 0.5 euro per $\mathrm{kg}$ ) down to $5 \%$. Import of pedigree breeder animals continues to be eligible for zero duty.

The introduction of new rates of import duties fostered the growth of pork imports. Imports of fresh and chilled pork in the IV quarter of 2012 exceeded the respective 2011 indicators by $9.8 \%$. As a result imports of pork (not including sub-products and fat) in 2012 were almost record high - about 750,000 tons (Fig. 2).

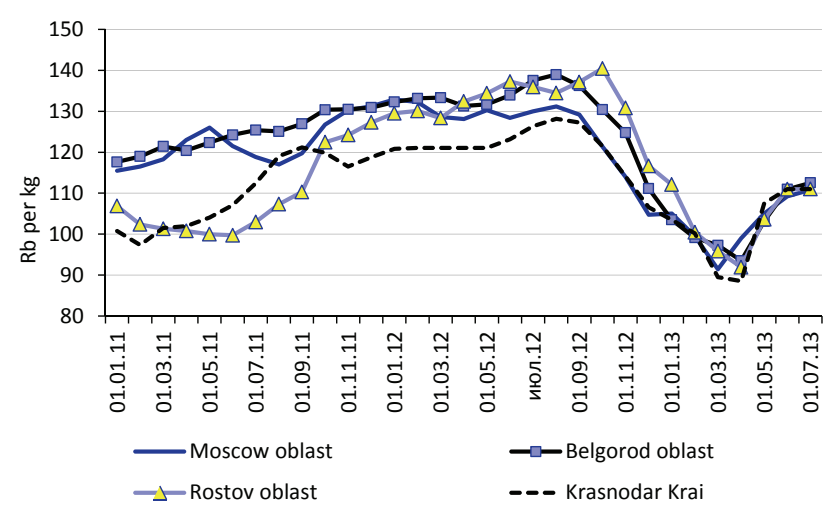

Source: IKAR.

Fig. 1. Dynamics of domestic producer prices for pork (slaughter weight, VAT included) in selected regions of the Russian Federation

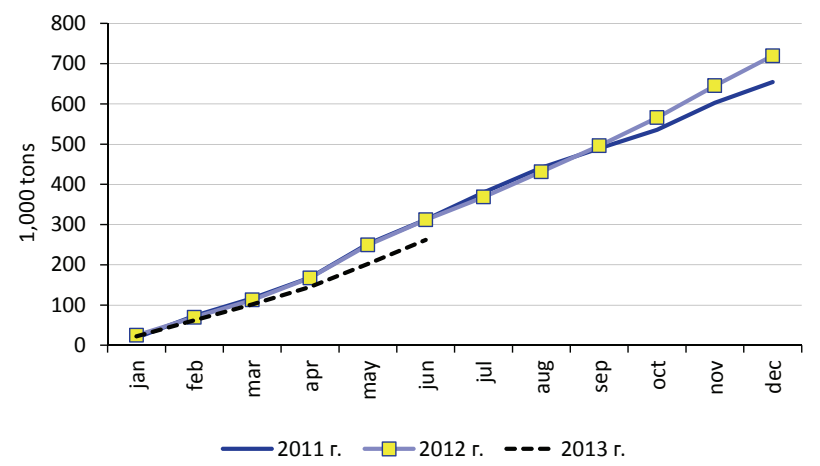

Note. Less trade with the Republics of Belarus and Kazakhstan. Source: Federal Customs Service of the Russian Federation. Fig. 2. Imports of pork (cumulative total from the beginning of each year)

However, from the beginning of 2013 imports notably shrank. In the conditions of more liberal customs and tariff regime the supply of live commercial pigs to Russia was constrained by the ban of "Rospotrebnadzor" [the Russian Service for Consumer Rights Protection]. Due to the ad-hoc restrictions on supplies from selected countries imports of pork in January-March 2013 were $11 \%$ below indicators of the respective period of 2012 and by early July they lagged behind by 


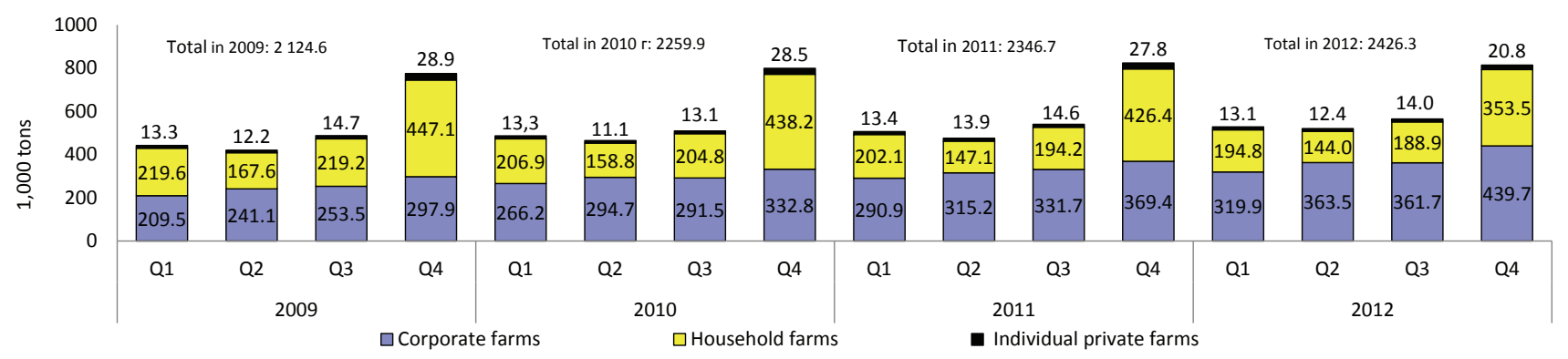

Source: Rosstat.

Fig. 3. Output of pork (slaughter weight) by types of farms

already $17 \%$. Still, the inflow of cheaper imported products has lowered the price ceiling for pork in Russia.

In 2012 the production of pork in Russia grew by $3.4 \%$ up to $2,426,300$ tons with the industrial sector accounting for the major part of this increase - its output was up by more than $13.5 \%$ (Fig. 3). So, additional volumes were supplied to the market aggravating the price situation. A noticeable growth of domestic production was observed from July to December 2012 and was most remarkable in the Central Federal District where it reached about $40 \%$ following the putting in operation of some new pig complexes.

Due to the inertia of pig raising sector, in 2013 the population of animals therein continued growing as investment projects launched in the previous years came to the completion (Fig. 4). The number of pigs in corporate farms as of July 1, 2013 totaled $14.7 \mathrm{~m}$ heads versus $12.6 \mathrm{~m}$ heads as of the same date the year before. In the first half of 2013 the live weight of pigs slaughtered in corporate farms reached 1,184,900 tons while the respective indicator for 2012 was $27.8 \%$ lower - only 927,500 tons.

High growth rates of 2013 indicators against the level of the previous year are registered in almost all the federal districts except the Southern one where as of July 1, 2013 the number of pigs was $24.7 \%$ below that of July 2012 (230,700 heads). The highest growth rates of pig population are observed in the Central Federal District (+27.2\% as compared with 2012).

High prices for feeds constituted another factor of profitability decline in pig raising. They grew due to the 2012 drought and the resulting rise of prices for grain (Fig. 5) and affected the cost of production in the pig sector.

The situation for Russian pig producers was aggravated by the fact that negative price dynamics coincided with the seasonal decrease of consumer and processor demand for pork in the Lenten period that lasted till the beginning of May.

In these conditions some investors in the sector started to abandon their projects. In March 2013 the leading producer of pork - agribusiness holding Mi-

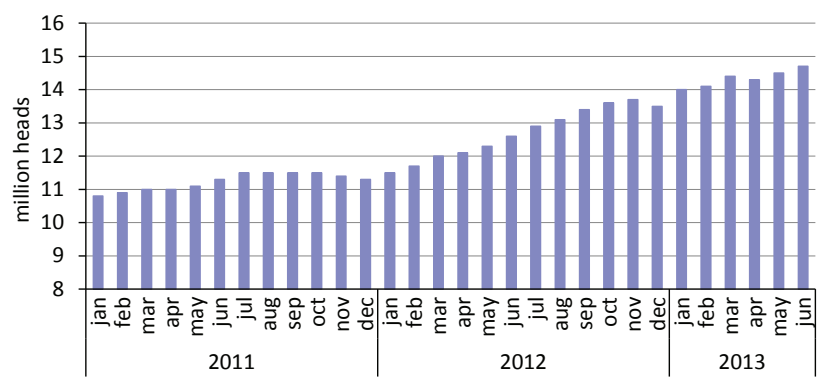

Note: as of the beginning of each month.

Source: Rosstat.

Fig. 4. Number of pigs in corporate farms

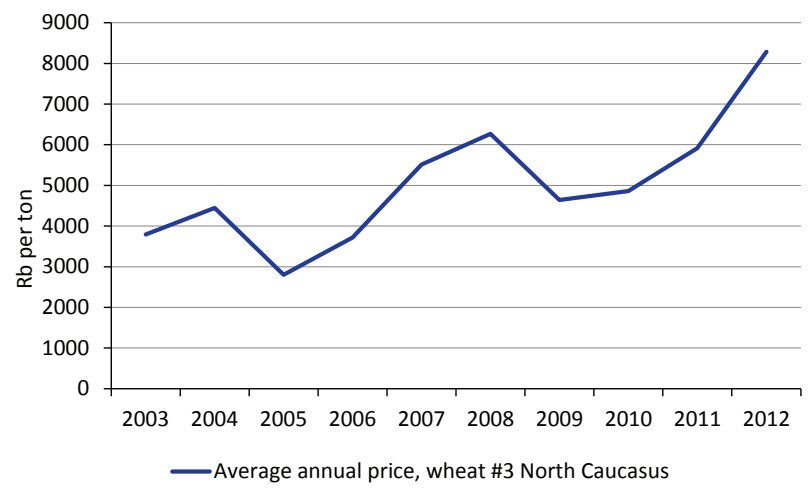

Source: Sovecon,

Fig. 5. Dynamics of grain prices

ratorg - declared the suspension of its investment projects under which 10 pig raising complexes were to be built in Kursk oblast. At present Miratorg has already put in operation 4 such complexes in the region that have reached their full production capacity 50,000 tons of pork (live weight) per year.

Protective actions against import and other tools of state support to pig breeders drove the development of pig raising in Russia. Owing to the active state support of the sector (subsidies to producers, customs and tariff regulation of import) prices for pork on the domestic market were kept at a high level as compared with the world prices (Fig. 6). In August 2012 wholesale prices for pork (slaughter weight) in the US averaged \$1.6 per 
RATING OF THE LARGEST PORK PRODUCERS IN THE RUSSIAN FEDERATION BASED ON 2012 PERFORMANCE*

\begin{tabular}{|c|c|c|c|}
\hline Rating & Producer & $\begin{array}{l}\text { Output of pork (live weight) } \\
\text { in } 2012,1,000 \text { tons }\end{array}$ & $\begin{array}{l}\text { Share in the total industrial pork production in } \\
\text { the Russian Federation (live weight) in } 2012\end{array}$ \\
\hline 1 & GC MIRATORG & 241.1 & $11.4 \%$ \\
\hline 2 & LLC GC AGRO-BELOGOR'E & 117.5 & $5.6 \%$ \\
\hline 3 & GC CHERKIZOVO & 115.0 & $5.5 \%$ \\
\hline 4 & GC Rusagro & 68.5 & $3.2 \%$ \\
\hline 5 & LLC COPITANIYA & 64.0 & $3.0 \%$ \\
\hline 6 & LLC PRODO management & 55.4 & $2.6 \%$ \\
\hline 7 & CJSC Agrarnaya Gruppa & 53.1 & $2.5 \%$ \\
\hline 8 & GC COSMOS GROUP & 39.7 & $1.9 \%$ \\
\hline 9 & CJSC Eksima & 39.6 & $1.9 \%$ \\
\hline 10 & LLC Kamskiy Bacon & 35.3 & $1.7 \%$ \\
\hline \multicolumn{2}{|c|}{ Total for the TOP 10 enterprises } & 829.2 & $39.3 \%$ \\
\hline \multicolumn{2}{|c|}{ Total for the TOP 20 enterprises } & 1111.7 & $52.7 \%$ \\
\hline \multicolumn{2}{|c|}{$\begin{array}{l}\text { Total industrial pork produc- } \\
\text { tion in the Russian Federation }\end{array}$} & 2107.8 & $100.0 \%$ \\
\hline
\end{tabular}

* Industrial pork production in the Russian Federation includes output of corporate and individual private farms.

Source: National Union of Pig Producers.

$\mathrm{kg}$, in Canada - \$1.5 per kg, in China - \$3.4 per kg, in Germany - \$2.4 per kg, in Denmark- \$2.1 per kg, in Russia (the Central Federal District, $1^{\text {st }}$ category pork) $-\$ 4.3$ per kg.

Following the accession to WTO the period of high prices for pork in Russia came to an end. Protective measures in the sector are no longer sufficient for fighting off possible import; instead, the improvement of competitiveness is essential. It will be accompanied by the withdrawal of non-modernized and household farms from the market and their replacement by companies with high performance indicators. Pig raising complexes with their own feed and processing capacities and retail network will gain an advantage.

The signs of consolidation in the pig raising sector can already be detected. While in 2010 the three biggest producers of pork (Group of Companies (hereinafter GC) Miratorg, LLC GC Agro-Belogor'e, GC Cherkizovo) accounted for $17.6 \%$ of the industrial pork production in the Russian Federation (includes output of corporate and individual private farms, live weight), in 2012 their share grew up to $22.5 \%$, first of all owing to the increase of Miratorg's output from 130,630 tons (7.2\%) up to 241,100 tons $(11.4 \%)^{1}$. In 2010 TOP 20 Russian pig raising farms produced $47.7 \%$ of pork, in 2012 - 52.7\% (Table 1). Their contribution grew in spite of the fact that the output of some producers included in this rating fell and they respectively lost their market share.

The situation on the market can change following the decision taken by the RF Government in response to the spread of African swine fever (ASF). According

1 Data of the National Union of Pig Producers.

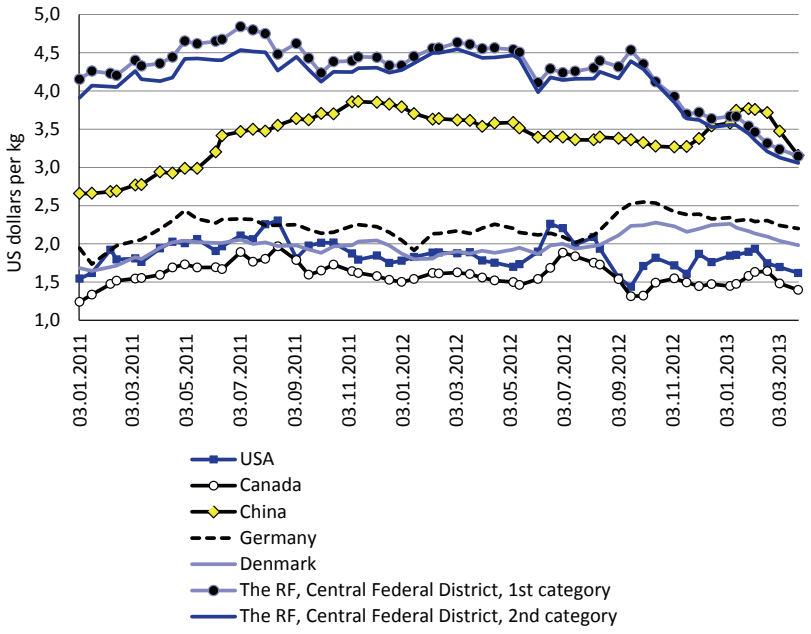

Source: Information and Analytical Agency "EMEAT".

Fig. 6. Dynamics of prices for pork (slaughter weight)

to the data of Rosselkhoznadzor [the Federal Service for Veterinary and Phytosanitary Surveillance] beginning from 2007 ASF was registered in 31 regions - constituent members of the Federation, over 909,000 pigs were condemned and liquidated. The compensation for condemnation of animals exceeded Rb 2.3bn. The situation deteriorated in June 2013 when cases of concealing ASF infection were revealed in Tver, Volgograd and other regions. It's obvious that the infection is scattering from ASF-endemic areas (the Southern Federal District and Tver oblast) and gradually seizing new regions. This can result in the contamination of the whole European part of the Russian Federation.

Due to the aggravation of ASF situation the solution of this problem has mounted to the level of the govern- 
ment that proposes to prohibit the keeping of pigs in farms failing to comply with biological safety requirements. This primarily concerns household farms and small farms unable to provide the adequate level of disease protection. According to estimates of the $\mathrm{Na}$ tional Meat Association about 30\% of pig population in the country is kept in household farms and 15\% - in old farms with insufficient level of biological security. The major pig production region of Russia - Belgorod oblast that accounts for $17 \%$ of the total national pig inventories - has already declared the launching of the program for buying out pigs from households at the price of $\mathrm{Rb} 60$ per $\mathrm{kg}$ of live weight. For reference - as of July 2013 the average purchase price for pigs in Belgorod oblast amounted to $\mathrm{Rb} 69$ per kg of live weight (VAT not included) ${ }^{1}$.

This measure will foster the offsetting of pig population drop in household and old farms by its increase in industrial enterprises and large agribusiness holdings. In order to support domestic pig producers the gov-

1 Data of IKAR. ernment has announced the allocation of direct subsidies to pig raising complexes in the amount of $\mathrm{Rb} 9$ per kg of pork.

The situation on the pork market improved already in the $I I$ quarter of 2013 . For instance, in the period from January to June prices for wheat (class 3, EXW North Caucasus) fell from Rb 11,200 per ton down to $\mathrm{Rb} 9,600$ per ton ${ }^{2}$. In July the price for pork was 15-20\% higher than in March ${ }^{3}$. Still, the accession to WTO has brought to light the problems faced by the sector and determined the guidelines for its further development: the improvement of domestic output competitiveness as compared with the imported products, the withdrawal of nonefficient producers from the market and further consolidation of the sector by industrial enterprises and agribusiness holdings having their own capacities for feed supply and meat processing as well as a developed distribution network.

2 Data of Sovecon.

3 Data of IKAR. 